\title{
Insularity and Cosmopolitanism: Islands of the Mediterranean - a Carousel in the Memory of Lawrence Durrell
}

\section{Giuseppina Semola}

\section{(2) OpenEdition \\ Journals}

Electronic version

URL: http://journals.openedition.org/transtexts/226

DOI: $10.4000 /$ transtexts.226

ISSN: 2105-2549

Publisher

Gregory B. Lee

\section{Printed version}

Date of publication: 1 January 2008

Number of pages: 134-148

ISSN: 1771-2084

\section{Electronic reference}

Giuseppina Semola, «Insularity and Cosmopolitanism: Islands of the Mediterranean - a Carousel in the Memory of Lawrence Durrell », Transtext(e)s Transcultures 跨文本跨文化 [Online], Hors série | 2008, Online since 14 September 2009, connection on 19 April 2019. URL : http://journals.openedition.org/ transtexts/226 ; DOI : 10.4000/transtexts.226 


\title{
Insularity and Cosmopolitanism: Islands of the Mediterranean - a Carousel in the Memory of Lawrence Durrell.
}

\author{
GiUseppina SEMOLA \\ Aristote University - Thessaloniki
}

In my view Sicilian Carousel results in a contemplation of Durrell's ideas on insularity, and a return to places dear to his heart - particularly Cyprus which recurs in his references, both tragic and pleasant. Cyprus is the core of his attempts to rationalise concepts such as insularity, Mediterraneity and Hellenism. Cyprus, Greece and Italy are indissolubly tied, even geologically, by the seismological fault that unifies and stirs them as it stirs Durrell's restless spirit, that, in his wandering and attempts to settle in this or that Mediterranean island, is in search of his existential identity, but is continually rejected by the places he loves so much. Is this due to imbalances caused by the historical geopolitical events, or rather to escapism? The writer's mind wavers between the idea of insularity as, from one hand, a spatial circumscription preserving one's identity and, on the other, as a possibility to escape via the surrounding sea, in search of new existential perspectives. Durrell's departure reveals his inability, as an archetypical cosmopolitan, to handle insularity as a permanent state of life as he metaphorically admits in the poem that ends his book.

In this presentation, I intend to examine the world of the islands, seen through the eyes of Lawrence Durrell, with a reference to his book titled Sicilian Carousel, where 
he returns to examine and explore concepts such as Hellenism and «Mediterraneity» and maturing insularity on Corfu, Rhodes and Cyprus, the big Mediterranean islands where he had spent earlier years.

I will attempt to evaluate ways in which Sicilian Carousel reflects the idea of insularity in its double and opposite meaning; from one side as a spatial limit to movement to preserve his own identity or, from the other side, as a place from which to escape through the surrounding sea, but, at the same time, offers endless routes of flight in search of new existential perspectives.

In conclusion, I will examine the degree to which Durrell's departure, (in Italian «allontanamento»), from the yearned for Mediterranean islands is due exclusively to geopolitical factors or rather to the inability of the writer, typically cosmopolitan, to endure insularity as a permanent state of life.

Durrell comes to Sicily in July 1975, twenty years after having written the last volume of his Trilogy on the Mediterranean Islands, Corfu, Rhodes and Cyprus. He comes to close the cycle with the Italian island: «The biggest and the most beautiful», and to complete the image of an aesthetic myth, that nourished his work; to conclude a dream that guided his past. ${ }^{1}$ The circle, the myth and the dream of Mediterraneity. After the tour, commissioned by a travel agency, he wrote Sicilian Carousel, (his last book on the Mediterranean Islands), where he talks of the historical and mythical stratification of the great Italian island. Not only the landscapes, but also the memories, are set in a frame of mythical and historical associations. Acting as spiritual guide to Durrell is Martine, a friend from Cyprus, now dead, who wrote letters to him from Sicily. She, like the author, suffered from «island mania». Through such letters, Durrell establishes a voice from the past, reviving the cultural climate in which his meditations on «Mediterranity» mature.

The book assumes the structure of a travel book through a series of connected images and autobiographical, historical, philosophical and narrative layers. The elements contained in the book are past topographic memory and resilience mixed with a subtlety hidden by its unusual construction which leads to the re-birth and catharsis at the end of the book.

Durrell returns to the Mediterranean that for him had established the realization of a Utopia of aesthetics and existentialism. The book describes and focuses on different islands but, at the same time, in his continual comparisons with other

\footnotetext{
${ }^{1}$ Lawrence Durrell, Sicilian Carousel, New York, Faber and Faber, 1977, p. 19.
} 


\section{Giuseppina Semola}

Mediterranean islands where he lived, Sicilian Carousel appears to us readers as the last of the islands series a series to become a tetralogy.

From the first pages of the book, Durrell seems to emphasise not only ties of characters, but also geological ones between the Greek islands and Sicily, Cyprus in particular, in the sense that the concept of seismological fault lines and earthquakes connects them from the geographic point of view. He recalls also common temperamental characteristics which extend from Sicily to the Middle East.

Durrell says that in Sicily he

was reminded, too that the volcanic crack which here traversed the southern tip of Sicily passed also through the Ionian Sea, under Xante and a part of Greece near Corinth, and finally through Cyprus where it usually tore Paphos apart ..... If you drew a line along the earth-crack, the long fault which ends somewhere in Persia I suppose ....could one find similarities of temperament and outlook in the inhabitants who live along it? ${ }^{2}$

The trip around the Italian island offers a chance for the author to undertake a final comprehensive review of that world which he longed for to associate himself in his life and in his body of work. The book on Sicily, which turns out to be «déjà vu» of a landscape inwardly prefigured, offers the opportunity, in a basically retrospective key, to solidify earlier reflections and meditations. Durrell effectively pursues a precise objective on his trip: to track down new source materials in order to hold the present moment in the immobility of a significant repetition. His observations of Sicily concur with the interpretation which has already been given to the author either by the letters of his friend Martine or by his own reflections, matured by his previous travels in the Greek islands.

Not only the landscapes, but also memories, are set in a frame of mythical and historical associations. This happens above all where he talks about the olive and the carob trees, to which he dedicates whole chapters: there the forebodings of the return and of revisiting the past insinuate themselves, in a channelling into the present of past memories. In fact, Durrell says,

Syracuse, where we would have spent a day and a night in search of the past,

${ }^{2}$ Lawrence Durrell, pp. 27-28 
leading the reader through the past in order to enlighten him about the mystery of his encounter with the present. ${ }^{3}$

In this way, the writer is close to the reader, to the doubts and questions of modern man. The writer uses this device with the peculiarities of the post- modernism: lacking determination, depth and reflective self reference, leaving the reader free to choose his own interpretation at the end of the book.

Durrell, was a great traveller, but, with the exception of his definitive departure from Great Britain to Corfu, travel for him did not assume the aspect of a withdrawal but rather his residencies became attempts to settle in places of his choice and, in particular, in that fluid, dynamic, jagged Mediterranean and in the Greek islands.

Corfu, Rhodes and Cyprus, situated in an oblique line which goes away from Europe towards the Asiatic shore, constitute a geographic figurative archipelago in Durell's life. Those islands are lined up along a line that goes more and more away from Europe, as well as from Greece, to get closer to Asia.

Every time the violence of history, lack of understanding or a particular conflict situation, (World War II or colonial conflicts), obliged Durrell to leave one island and move to another, ruining his obstinate plan to settle down.

Durrell's biography demonstrates that he has always been adept in the art of travelling - maybe thanks to his Indian roots. Travel for him is a function of good natured curiosity. In contrast with this character predisposition of a tendency to cosmopolitism, in a dichotomy that will accompany him throughout his whole life, there is in Durrell the choice to live on islands. Such a choice is equivalent to choose physically the isolation, the idea of the unmistakable enclosure, the Isle, a simple sunny place, a dream reality to evoke pure happiness, with history and folklore, a landscape with characters, a pastoral world in which to integrate.

Durrell feels himself at the centre of a magic circle, as a pure spatial and temporal interference, a sensitive and receptive entity, ready to establish relations with the locals, meeting them in taverns and, while eating good food and tasting excellent wine, to become a philosopher host, whose brilliant, speculative conversation creates an amalgam of wit, history, and sentimental love of place. At the same time, he is delighted to translate this experience in literary works to exalt his lifestyle and

${ }^{3}$ Lawrence Durrell, pp. 44-45 


\section{Giuseppina Semola}

the idea of insularity itself. Later, when events - the incomprehension or the unjustified wars - compelled him to turn away and to abandon one island after another, the island itself is still vivid in his mind and close to him. So the splendour of his present in each island is preserved in the memories and nostalgia of the past.

Since his sojourn in Corfu, Durrell had begun to build the image of an isolated island, «Mediterranean», sun-washed, sea-stroked, that, in singing prose in his first book of the trilogy, he defines as a place where «the blue really begins». As he moves from place to place, the particular name of his island changes, from Corfu to Crete, to Rhodes and, finally, to Cyprus in the fifties. But however it is used as the subject of his trilogy of island portrays, say, or as the point of departure and return, (in The Alexandria Quartet and in Sicilian Carousel), it retains its isolating, healing function. It becomes a place, even when it is war-torn Cyprus, for the isolation of the cities in which the artist finds much of his material, a place in which the artist can compose his fragmented experience by linking it to the landscape soaked in the past, a landscape richer and older and more meaningful than this modern, chaotic one. For the Mediterranean world, «where mythology walks in a wave.... and the islands are» has entered Durrell's work in almost precisely the same way his childhood memories of Tibet have entered it. It has given him more than a locale for his work; far more subtly - in imagery, in metaphors, in symbols - it has become an integral part of the soul, mind and memory of the poet, a living tissue of the work itself.

In Sicilian Carousel, the trip in Sicily, for Durrell, is not so much the exploration of something new but an attempt to re-discover a lost world - the Mediterranean ecstasy.

It is with this recollective objective that Durrell goes to Sicily. Already, since the very first pages of the book, the author's awareness of the concept of island is evident as something circumscribed, associated with a certain brand of conservatism pertaining to the preservation of identity.

Durrell, very skilful in his use of images, metaphors and symbols, describes Sicily, seen from the aeroplane with

an air vaguely threatening as it had a sort of minatory, defensive air;

Further he defines the island as being with 
indomitable flanks. From so high one could see the lateral tug of the maindeep furling and unfurling its waters along those indomitable flanks of the island. And all below lay bathed in a calm green afterglow of dusk. It looked huge and sleemy frustrated, like a Minoan bull. ${ }^{4}$

And the author reverts to his concept of islands as circumscribed places, that tend to preserve their own identity, when he quotes:

The islands of the mid-channel are the earthquake ones, and they tend to be somewhat boisterous. Never accuse a Sicilian to be a Roman, nor a Cretan ob being from anywhere else. It was true, but somehow this kind of argument never led far enough. ${ }^{5}$

And again the same concept:

What was Sicily, what was a Sicilian? I had already noticed the strongly separatist temper of the inhabitants which had won them (but only recently) a measure of autonomy. The island was too big and too full of vigorously original character to be treated as if it was a backward department of a run down post-war Italy. ${ }^{6}$

And further in the book he describes Sicily as an idyllic place, isolated in space and time, that maintains its traditional identity:

And in the little streets there were unforgotten corners of the real Italy -by which I mean the peasant Italy with its firmly anchored values and purity of heart. ${ }^{7}$

And again talking about Eschilo, who chose Gela, a quiet village in Sicily, to live out his declining days for

the absence of a harbour, the seclusion of the quiet little town on its promontory high over the sea, its remoteness from the bustle of everyday politics.......were the very things which made it precious in the eyes of Aeschylus. ${ }^{8}$

\footnotetext{
${ }^{4}$ Lawrence Durrell, p. 18.

${ }^{5}$ Lawrence Durrell, p. 28.

${ }^{6}$ Lawrence Durrell, p. 112.

${ }^{7}$ Lawrence Durrell, 1977, p. 208.

${ }^{8}$ Lawrence Durrell, 1977, p. 83.
} 


\section{Giuseppina Semola}

Therefore, Sicily and the Mediterranean islands are common in the sense that they are idyllic places in which to enjoy a simple fulfilled life, a sense of being in the right place, with the right people: not pleasure that cloys, or ecstasy that exhausts, but simple happiness, the sun, the sea, sound dreamless sleep, trusted companionship, the taste of spring water.

But in Sicilian Carousel there is also the consciousness that the concept of insularity does not consist only in the happiness given by the sun, the sails, the fishes, the faithful friends or by the spring waters. The island is limited by the sea that, from one side, reinforces the sense of belonging, from the other side, implying enclosing)in itself the double notion of arrival and departure, can be the cause of deep and unforeseeable shifts. Such change, in terms of openings, - for example in the most banal sense of travel connected with the tourist flux and the consequent enrichment that comes from it, linked therefore with the more general concept of cosmopolitanism - might be positive. On the other end, such mutation might lead to irreparable scars in the sense of ecological and anthropological violations of an environment linked to invasions and war.

For this reason, the insularity is also inseparably associated with the concept of violation of boundaries - that is invasions, peaceful or violent. With this consciousness in Sicilian Carousel Durrell quotes the case of Cyprus, where, like in Sicily «many strains, many invasions of tribes from different quarters must be envisaged» and it is a land's destiny, because of vocations or geographical location between east and west to continuous disruptions and invasions, from which it is still suffering. ${ }^{9}$

In Sicilian Carousel Durrell relives the dramatic moments of the arrival of the troops before his quick departure from Cyprus.

It was the last summer before the Fall...with the arrival of the troops and the gradually mounting toll of incidents and counter-incidents, tempers wore thin and at last wore out altogether. All our hopes of a peaceful and productive life in this paradisiacal place went up in smoke...Then, abruptly, like the explosions from some Etna of the mind, the whole thing overturned and both guilty and innocent were drenched in blood. ${ }^{10}$

${ }_{9}^{9}$ Lawrence Durrell, p. 67.

${ }^{10}$ Lawrence Durrell, pp. 50-52. 
The idea of insularity meant, in its dualism between a paradise to protect from the «invasions» of the outside world and in which to live and as a place exposed to every violation from which to escape, is, in Durrell, intertwined with the idea of the Mediterranean itself. The Mediterranean is a spatial circumscription that shapes a specific character, a certain attitude, an identifiable temperament, a way of life, a particular vision of the world; in a word it is associated with a certain brand of conservatism, isolationism and preservation of identity where Durrell really fulfils himself - finds in them a resonance that exactly suited his talent and his personality. But the Mediterranean is also a place from which one can be seduced, even unconsciously, to escape, like a new Ulysses, to grow, to know, to be different, to be something else or someone else apart from that permanence in a familiar place, where one is recognized as belonging to it, not an outsider, but assured. This dichotomy between settling and escaping wracked, consciously or unconsciously, the writer's brain for his whole life.

Complementary to the concept of insularity is that of the sea, that Durrell perceives in a double rôle of defensive bulwark or as an aggression against the space circumscribed by itself, that means it is seen as both a limit and an unlimited vista. To this second sinister aspect of the sea, Durrell often refers in Sicilian Carousel. Beside what I quoted before on the purpouse of the sea that

with the lateral tug of the maindeep furling and unfurling its waters along those indomitable flanks of the island.

that appeared for this interference

sad and slightly frustrated. ${ }^{11}$

Durrell confirms the concept of the sea from which to protect oneself in the context of Sicily with

Crete! Cyprus! It was like them, an island of the mid- channel-the front line of defense against the huge seas combing up from Africa. Perhaps even the vegetation echoed this, as it does in Crete? I felt at once reassured , as if I had managed to situate the island more clearly in my mind. Magna Grecia!12

The sea continues to appear as a destructive power on the purpose of the decade of the temple of Apollo in Ortigia

${ }^{11}$ Lawrence Durrell, p. 18.

12 Lawrence Durrell, p. 18. 


\section{Giuseppina Semola}

The answer of course is the sea with its salt which rots everything. ${ }^{13}$

and of the statue of Aphrodite Venus in Reflections on Marine Venus, the book voted to the isle of Rhodes

The central image of the marine Venus - a statue of a woman, period uncertain, found at the bottom of Rhodes harbour, damaged by sea water

But in the context of the encounter of opposite worlds and civilizations, and in the context of Sicily and Cyprus, as islands invaded by foreign populations, Durrell observes that, in Sicily, the sea played also a positive role, bringing culture and welfare, fusing harmoniously the tensions derived from the clash between Eastern and Western worlds in contrast with what happened in Cyprus, where the sea was bearer of tragic tensions which last until the present.

In this purpose Durrell describes Cyprus

where the Turks knocked off the towers of medieval cathedrals to add minarets; and of course the pictures one has seen of the Acropolis transformed into a mosque. ${ }^{14}$

while Durrell observes that among the invasions undergone by Sicily, some of them were not so harmful, like the Arabs one who

were astonishingly inventive and sensitive these newcomers from over the water, people with the austere desert as an inheritance. For the Arab knows what water is, it is more precious to him almost than oxygen. ${ }^{15}$

and they didn't destroy the island, but introduced new resources and strengthened the existing ones.

So were rural areas resettled, inheritance laws revised, ancient waterways brought back into use for irrigation. They were planters of skill and choice, they brought in citrus, sugar-cane, flax, the date palm, cotton, the mulberry with its silkworms, melon, papyrus and pistachio. Nor was it only above ground for they were skilful miners and here they found silver, lead,

\footnotetext{
${ }^{13}$ Lawrence Durrell, p. 87.

${ }^{14}$ Lawrence Durrell, p. 196.

${ }^{15}$ Lawrence Durrell, p. 114.
} 
mercury, sulphur, naphtha, and vitriol - not to mention alum and antimony.

The extensive salt-pans of today date from their inspired creative rule. ${ }^{16}$

What makes Sicilian Carousel interesting, and distinguishes it from the other books of his famous trilogy, is the character of existential consumptive that Durrell gives it and its structure assumes a particular cyclical course: after the tourist carousel so long postponed and intimately refused, the true travel, the real return to the ideal island and to the Mediterranean, starts at the end of the book, at the end of the tour purely explorative. Immersing himself in a more hidden and secret Sicily, one of the least known places and of the little villages half desert, «to fill in the jigsaw» 17 places which echoes with the idea of insularity in which he has always identified himself, he found out the essence of the Italian island which is more in tune with his intimate heart and in his existential aspirations. This results, in the heart of the writer, anointing Sicily as the ideal island looked for in his previous travels to the islands of the trilogy.

Contemporarily, Durrell notes with bitterness the fact that, for him, a future on the Mediterranean islands does not exist and that the idyllic island exists for him only as a utopian dream. With this belief, before his final departure from the island, Durrell, in the following way, concludes his trip:

I burnt Martine's letters on a deserted beach near Messina...it was the end of a whole epoch, and, appropriately enough, I spent a dawn in the most beautiful theatre in the world... ${ }^{18}$

Therefore, to conclude this ideal trip in the Mediterranean, in Greece, in the islands, in Cyprus, but also in Sicily, the denouement of the "Carousel» is symbolically represented by the cathartic rite of the burning of Martine's letters that represents the departure of the writer from his past and from the idea to settle in an ideal island of the Mediterranean. This ritual is a sort of liberation from his dream to live in a paradisiacal world full of colour, sounds, light, shadow and rhythm, as the world of black cherries, sail, dust, arbutus, fishes. It is a conscious awareness of the end of the dream he longed for for more than 20 years. It is with some regret that Durrell realizes «to be back in Europe» and to be on the point of changing «the whole key» (key of register). (p.209). The new tour of the isle of Sicily that he is about to undertake will be a little different from the Sicilian Carousel, it will be, as is

\footnotetext{
${ }^{16}$ Lawrence Durrell, p. 114.

${ }_{17}$ Lawrence Durrell, p. 214.

${ }^{18}$ Lawrence Durrell, pp. 215-216.
} 


\section{Giuseppina Semola}

ironically indicated in the subtitle of the text, the true «travel of an Englishman in Sicily», of which, as a statement, Durrell gives us only a few notes and a poem dedicated to the little village of Bisacquino.

Sicilian Carousel can be seen as a review of Durrell's ideas of insularity meant as Mediterranean and of Durrell's life: more than a book related to a real voyage, a diary of a fictional escape, of a return, all lived in the memory and in the nostalgia of those islands, the landscape and characters of which remained indelibly engraved in the soul of the writer. In effect, since long ago, Durrell had understood that personality, as something with fixed attributes, is an illusion and that his own personality was marked by curiosity and desire for discovery and that all his life would have been conditioned by the dualism between the travelling, even in the introspective and intimate way, and residing, (in places of his choice), that had been clearly expressed in his previous books of the trilogy.

In Prospero's cell, in his first contact with the Greek world, Durrell says:

Other countries may offer you discoveries in manners or lore or landscape; Greece offers you something harder - the discovery of yourself.

And the opening of Bitter lemons, is an aphoristic variation of the final paragraph of the first section of Prospero's cell, more generalized, more mature and more hesitant:

Journeys, like artists, are born and not made. A thousand differing circumstances contribute to them, few of them willed or determined by the will - whatever we may think. They flower spontaneously out of the demands of our natures - and the best of them lead us not only outwards, in space, but inwards as well. Travel can be one of the most rewarding forms of introspection.

All journeys are fated, but Durrell knows now that introspection can, however acute, never offer one a final discovery of the self: only insight into a passing state of it.

At the very end of Sicilian Carousel, after the cathartic rite, the guide of the tour acts as a spokesman for Durrell's ideas about the motivations that induce people to travel: 
Travelling isn't honest. Everyone is trying to get away from something or else they would stay at home ...The others, well, I bet you have your own reasons too. ${ }^{19}$

And which were the good reasons for Durrell? Surely his awareness of his impossibility, surely due to cosmopolitan anxiety, that leads him, even unconsciously, to see himself as an exemplar of both the white and the black sides of the human condition, eager also in the desire for exploration, new knowledge, adventure, to pause for all time in an ideal island, destination that, as metaphorically expressed by the poem that the writer poses as a seal of Sicilian Carousel, will eventually be reached at the final landing-place of his life.

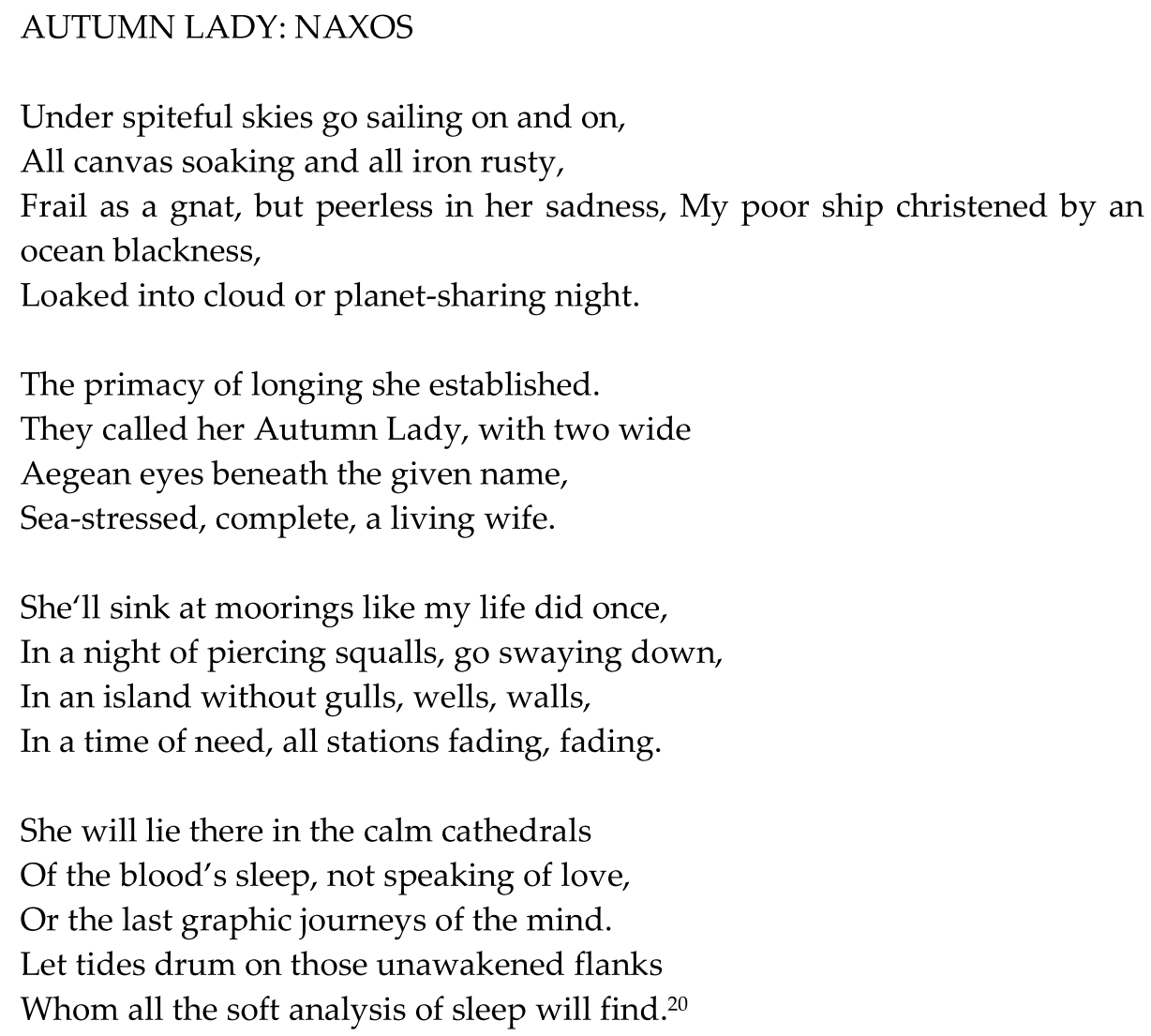

Naxos is the biggest of the Cyclades islands, but also Taormina's beach, (Naxos gardens), and also the name of the crooked ship in which Durrell identifies himself. And it is Durrell on the sunset path, at least as he says, but yet indomitable, who, as

${ }^{19}$ Lawrence Durrell, p. 216.

${ }^{20}$ Lawrence Durrell, p. 219. 


\section{Giuseppina Semola}

a reader of his book, in the nice poem, makes clear, a little bitterly disappointed, how for him insularity, meant as a place of peace, «an island without gulls, wells, walls» not disturbed by passions or desires for new travels, is in the end a Utopia, that he had thought to realize in his wandering sojourns in the Greek islands, whose tracks he came to find in Sicily, following the echoes of his and Martine's memories.

But this symbolic ship «christened by an ocean blackness» is destined to a continuous peregrination «go swaying down», establishing «the primacy of longing», of the long desire, to land in an island that does not exists. Such a primate will be realized only when the "Autumn Lady'll sink at mourings», that is when the poet's life will end. There prevails in Durrell's soul the perception of the idea of insularity as a vocation, frustrating both to leaving and to the departure, to the exile, sometime necessary, but sometime unconsciously craved. Durrell translates this discovery into human terms: At times people are conscious of themselves as individuals, but if they accept the fact of the continuum that exists in the melding of time and space, then people «may perhaps form ingredients of a single continuous stream of life».

Durrell, like D. H. Lawrence before him, rejected «the old stable ego of character» in favour of characterisation that is more amorphous and ambiguous. As Balthazar in The Alexandria Quartet says: «Each psyche is really an ant-hill of opposing predispositions. Personality as something with fixed attributes is an illusion». People, they too have no recognizable signposts to their personalities. When Justine in The Alexandria Quartet looks at her multi-faceted reflections in a dressmaker's mirror, she asks: «Why should not people show more than one profile at a time?» If space and time are relative and the human personality is not fixed, the cosmology of the age needs to reflect these uncertainties. The closest equivalent philosophical system, in Durrell's view, can be found in Eastern philosophies.

Life is a hard and bitter, though noble, business.

At the end of the book, a reflective, melancholic and thoughtful Durrell emerges. He talks of death, a Leopardian Durrell and to Leopardi, on the other hand, he quotes at the end of the second poem dedicated to Bisacquino:

Leopardi in the ticking mind,

Lay unknown like an exiled king,

Printing his dreams among the olive glades 
In orchards of discontent the fruitful word. ${ }^{21}$

He calls him «obscure king in exile». He quotes Leopardi who, in one of his most beautiful and very well known poems, surely known by an erudite like Durrell, The infinitewrote about a hedge: ${ }^{22}$

which prevents me from seeing most of the endless horizon. But when I sit and gaze, I imagine, in my thoughts endless spaces beyond the hedge, an all encompassing silence and a deeply profound quiet, to the point that my heart is almost overwhelmed. to flounder in this sea is sweet to me.

${ }^{21}$ Lawrence Durrell, Sicilian Carousel, Faber and Faber, 1977, p. 220.

22

\section{THE INFINITE}

This solitary hill has always been dear to me

And this hedge, which prevents me from seeing most of

The endless horizon.

But when I sit and gaze, I imagine, in my thoughts

Endless spaces beyond the hedge,

An all encompassing silence and a deeply profound quiet,

To the point that my heart is almost overwhelmed.

And when I hear the wind rustling through the trees

I compare its voice to the infinite silence.

And eternity occurs to me, and all the ages past,

And the present time, and its sound.

Amidst this immensity my thought drowns:

And to flounder in this sea is sweet to me.

\section{L'INFINITO}

Sempre caro mi fu quest'ermo colle, e questa siepe, che da tanta parte dell'ultimo orizzonte il guardo esclude. Ma sedendo e mirando, interminati spazi di là da quella, e sovrumani silenzi, e profondissima quiete io nel pensier mi fingo; ove per poco il cor non si spaura. E come il vento odo stormir tra queste piante, io quello infinito silenzio a questa voce vo comparando: e mi sovvien l'eterno, e le morte stagioni, e la presente e viva, e il suon di lei. Cosi tra questa immensità s'annega il pensier mio: e il naufragar m'è dolce in questo mare. 


\section{Giuseppina Semola}

Surely just for this, at the end of Sicilian Carousel, Durrell quotes him, because he feels very close to the Italian poet, where the sense of insularity, (isolation-exile) is very strong and it is represented by a fence that is easy to climb, but that the poet could not replace, because it was an interior, and social one, like in Durrell, in the way that each of the two writers «printed his dreams in orchards of discontent». 